\title{
Tourism Resilience Plan in Port Fairy under the Context of Climate Change
}

\author{
Xiaoyi Xuan, Mu Zhang \\ School of Management, Jinan University, Guangzhou, China \\ Email:eva_xuan@hotmail.com
}

How to cite this paper: Xuan, X.Y. and Zhang, M. (2018) Tourism Resilience Plan in Port Fairy under the Context of Climate Change. Journal of Service Science and Management, 11, 242-255.

https://doi.org/10.4236/jssm.2018.112017

Received: March 7, 2018

Accepted: April 25, 2018

Published: April 28, 2018

Copyright $\odot 2018$ by authors and Scientific Research Publishing Inc. This work is licensed under the Creative Commons Attribution International License (CC BY 4.0).

http://creativecommons.org/licenses/by/4.0/

\begin{abstract}
Nowadays, climate change is leading to play an increasing significant role in cities' tourism development. Particularly, sea level rising is one of climate changes to coastal cities. This paper, focusing on the current situation Port Fairy in Melbourne is facing and the key topic of tourism development, proposes a detailed action plan for retreat. It, firstly, defines key terms towards resilience and tourism resilience. Then, concrete problem analysis and critique is given. Lastly, a detailed action plan in three stages will be given to implement the recommendation.
\end{abstract}

\section{Keywords}

Tourism Resilience, Climate Change, Development Plan

\section{Introduction}

Climate change is increasingly influencing the development of human being and urban environment. Port Fairy in Melbourne is a typical coastal city facing sea level rising as a result of climate change. This paper, focusing on the current situation Port Fairy is facing and the key topic of tourism development, proposes a detailed action plan for retreat. Around the world, many coastal cities as famous tourism destinations are facing the similar challenge like Port Fairy in Melbourne. Once sea level rises, the tourism industry and local residents are influenced to large extent. The action plan for treat could be an example and provides some suggestions for other coastal cities to deal with seal level rising and achieve tourism resilience to ensure the economic development. However, the retreat plan has not been taken into action already and further assessment towards the plan should be taken.

The article is organised as follows: firstly, key terms towards resilience and 
tourism resilience are defined to ensure the accurate understanding; then, concrete problem analysis and critique is given towards Port Fairy in Melbourne; lastly, a detailed action plan in three stages will be given to implement the recommendation.

\section{Key Definitions}

\subsection{Resilience}

Bruneau et al. states that resilience depends on four properties: robustness (the physical strength to withstand a disturbance without functional degradation); redundancy (the extent to which system components are substitutable); resourcefulness (the capacity to identify problems and mobilize needed resources) and rapidity (the capacity to restore the system in a timely manner) [1].

Engineering resilience is defined as the ability of a system to return to an equilibrium or steady-state after a disturbance [1]. This disturbance can be either natural disasters or artificial crisis.

Different from engineering resilience, ecological resilience is "the magnitude of the disturbance that can be absorbed before the system changes its structure" [2], which lays stress on "the ability to persist and the ability to adapt" [2].

Evolutionary resilience, also named as socio-ecological resilience, is the ability of complex socio-ecological systems to change, adapt, and, crucially, transform in response to stresses and strains [3].

\subsection{Characteristics of Resilience}

Beilinconcludes the main four characteristics of resilience: diversity; modularity; feedback and redundancy. The concrete definitions are as follows: a) Diversity: It provides the source of options including both ecological mosaic (such as plant species palette)and the social mosaic (plethora of that communities can draw on for innovation and adaptation); b) Modularity: It refers to that how components in a system are linked; c) Feedback: Feedback informs how quickly and strongly the consequences of change in one part of the system will impact the other parts; d) Redundancy: Redundancy refers to the capacity to sustain sub-systems and functions to support overarching systems-the capacity to maintain multiple options [3]. A system is likely to be more robust if high levels of redundancy exist and can be actively built into social ecological systems.

\subsection{Strategies for Resilience}

Strategies for resilience are concluded in Figure 1.

\subsection{Tourism Resilience}

Indeed, numerous scholars have developed conceptual frameworks to elaborate the resilience and adaptiveness in the tourism sector relationship between tourism system and its reliance or adaptiveness [5]. In the practical term, Calgaro and Cochrane identify the actions for reducing vulnerability and building 


\begin{tabular}{|c|c|c|}
\hline \multicolumn{2}{|c|}{ Strategies for resilience } & Source \\
\hline \multirow{6}{*}{ Assume change and uncertainty } & Buffering & Wardekker et al.,2009 \\
\hline & Redundancy and modularization & Wardekker et al.,2009; Ahern 2011 \\
\hline & Evoking disturbance & Folke et al.,2003 \\
\hline & Strategic foresight & Wardekker et al.,2009 \\
\hline & Learning from crisis & Wardekker et al.,2009 \\
\hline & Adaptive planning & Ahern 2011 \\
\hline \multirow{3}{*}{$\begin{array}{l}\text { Nuture conditions for recovery } \\
\text { and renewal after disturbance }\end{array}$} & Social capital & Folke et al,2003;Ahern 2011 \\
\hline & Social-ecological memory & Folke et al.,2003 \\
\hline & Ecological diversity & Folke et al,2003; Ahern 2011 \\
\hline \multirow{2}{*}{$\begin{array}{l}\text { Combine different types of } \\
\text { knowledge for learning }\end{array}$} & $\begin{array}{l}\text { Combine experimental and } \\
\text { experiential knowledge }\end{array}$ & Folke et al.,2003 \\
\hline & Tight feedbacks & $\begin{array}{l}\text { Walker and salt,2006; Wardekker } \\
\text { et al.,2009 }\end{array}$ \\
\hline \multirow{2}{*}{$\begin{array}{l}\text { Create opportunities for self- } \\
\text { organization }\end{array}$} & $\begin{array}{l}\text { Multi-scale networks and } \\
\text { connectivity }\end{array}$ & Ahern 2011 \\
\hline & $\begin{array}{c}\text { Interplay between diversity and } \\
\text { disturbance }\end{array}$ & Folke et al.,2003 \\
\hline
\end{tabular}

Figure 1. Strategies for resilience [4].

resilience in Thailand after the Asian tsunami. Even in 2009, the UNWTO formally establishes a Tourism Resilience Committee, using "resilience" in the standard layman's sense instead of social-ecological intimations [6].

Cochrane explains how a resilient tourism system can be established. As shown in below, this system consists of three key elements: harness market forces, leadership and stakeholder cohesion, which is shown in Figure 2 [6].

"Harness market forces" emphasizes the role of market engagement in addressing social justice, environmental concerns as well as profit margins in the three-bottom-line sustainability [7]. Stakeholder cohesion and associative working is the second element, it considers all sectors (public, private and the third sectors) and their roles, strengths, and limitations. Through the coordination of all the stakeholders, resources can be exploited equitably while the needs of current and future generations are both considered [8]. Thirdly, consistent, and strong leadership is stressed, which can be reflected from the vision, plan and management and plays a significant role in reconcile the contradictions towards resource exploitation, market engagement and stakeholders [9]. Moreover, flexibility, learning and adaptability are required in the system. Flexibility escapes over-rigidity which may result in inability of accommodating stress. To achieve effective adaptability and flexibility, the aspects from other systems affecting SES also should be incorporated into regulations and institutions. Therefore, learning towards other relevant systems is required as well to ensure this understanding [6].

The following actions plan is developed through references of "strategies for resilience" and "the sphere of tourism resilience" to address the impacts of climate change (focuses on sea level rise) on tourism development.

\section{Initial Recommendations}

In the previous group presentation, team 4 proposed the recommendations for 


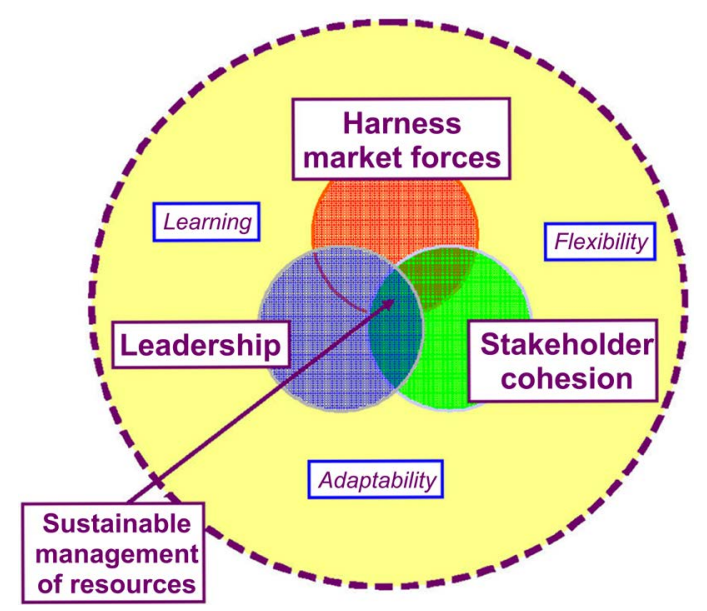

Figure 2. The sphere of tourism resilience [6].

tourism and sea level rise as: respond through Folk; protect Port Fairy; diversify tourism. "Respond through folk" is adopted as the initial recommendation for this plan. More specifically, it focused on gradual retreat, which intended to inform tourists about the challenges that Port Fairy is facing as the sea level is continuously rising and gives tourists deeper understanding of the relocation of the Folk Festival [10].

\section{Problem Analysis and Critique}

Problem analysis and critique is mainly based on the problems that the initial recommendation aims at and gives comprehensive considerations towards Port Fairy's current situation and challenges. The recommendation stated before is protecting Port Fairy, which contains the issues towards retreat due to climate change and relocation of the Folk Festival.

\subsection{Retreat}

The recommendation, based on climate change (especially sea level rise), proposes the plan to retreat of Port Fairy. This part intends to analyse the current problems of climate change and then have a discussion of retreat.

1) Climate change

As to the influence of climate change on Port Fairy, it mainly refers to storm surge and flood inundation in the short term and sea level rise in the long term due to Port Fairy's geographic location [13]. Port Fairy is a coastal town at the end of the Great Ocean Road, south-western Victoria, Australia. It is a typical community that is situated at the interface between river catchment, estuary and ocean [14], which makes this town vulnerable to natural environment.

a) Storm surge and flood inundation

Port Fairy has suffered storm surge and floor inundation many times in its history and it is predicted to experience increasing floods in the following years [11]. Figure 3 below shows the floods in the history and their flood level. In March 1946, Port Fairy experienced the highest flood level on record $(5.7 \mathrm{~m})$, 


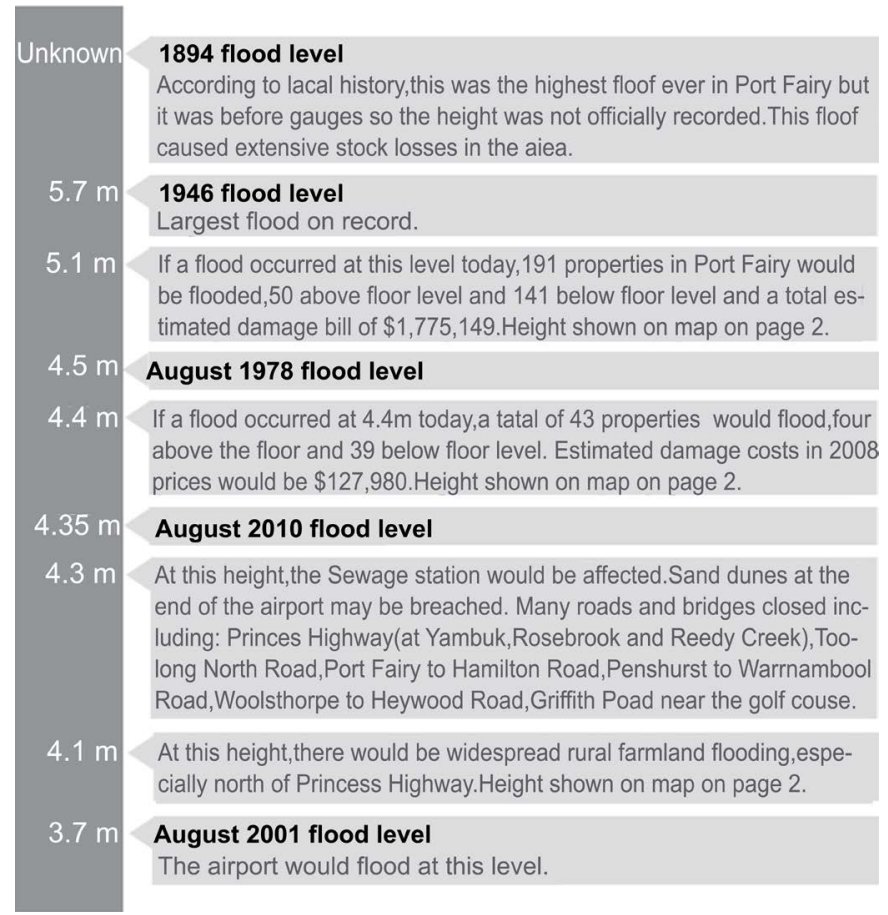

Figure 3. Local flood guide port fairy [11].

and then it continuously experienced floods in 1978, 2001 and 2010 [12].

Floods have severe impacts on human activities and properties. According to SES, the flood in 1946 leads to inundation of large quantities of properties, social infrastructures including roads and the bridge over the Moyne River and widespread mass evacuations [13].

b) Sea level rise

One of the most significant effects brought by climate change is sea level rise, which directly increase flood risk. Water Technology have designed a model to stimulate future scenarios on riverine flooding and storm surge inundation in Port and the findings are clear as Figure 4 shows:

2) Issues towards retreat

As stated above, sea level rise causes part of the town is inundated, therefore the initial recommendation of gradual retreat is supported and recommended. However, some significant issues towards retreat have not been addressed.

a) Building new Port Fairy

Group 4 did not mention the proposed destination for relocating Port Fairy as well as the amount of funds that are required in constructing new properties and infrastructures. It is also challenging to preserve the place character of the original town and incorporates it into the designs of new town.

b) Dealing with old Port Fairy

It is necessary to consider how to deal with the properties and infrastructures in old Port Fairy once the residents are moved out (Are they being demolished or be kept).

c) Persuading community to move 


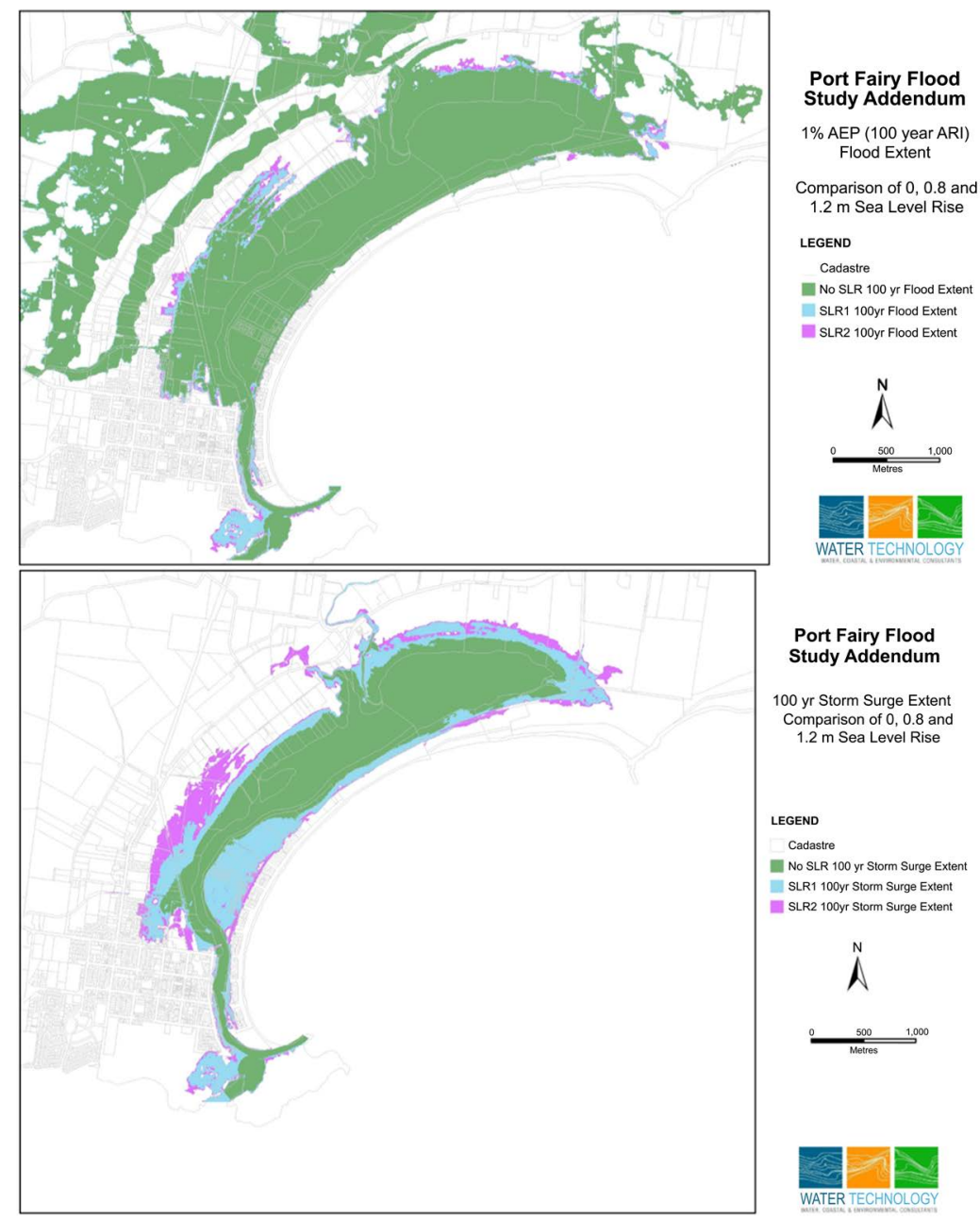

Figure 4. Comparisons of 100 year ARI flood extent and storm surge extent with $0,0.8$ and 1.2 sea level rise [14].

Through the consultations in Port Fairy, community members obviously have developed a good relationship with this town and they value the distinctive place character. In addition, some of residents in Port Fairy have not realized the challenge Port Fairy is facing and the worse condition Port Fairy will suffer with the rising sea level. Hence, educating residents about the climate change and persuading them to move ought to be considered.

\subsection{Relocation of Folk Festival}

The initial recommendation points out that Folk Festival will be relocated during the process of gradual retreat. However, the recommendation should consider the development of tourism industry holistically, rather than just focusing on single tourist event.

1) Tourism development in Port Fairy

Tourism industry plays a vital role in local economy. And it has some characteristics that can reflect some challenges that Port Fairy is facing.

a) Rely on domestic tourists 
According to Tourism Research Australia, in the last 5 years, the average number of visitors to Port Fairy is 237,133 while the average length of stay is 3 nights. Among these visitors, over 90 percent of them are from Australia, as the following Figure 5 shows [15].

The current development of tourism industry has showed its domestic seasonality. Obviously, January and March are the most popular seasons and the winter (June, July, August and September) is less popular, which is shown in Figure 6. It is necessary to consider how to promote a more balanced tourism industry around the whole year.

b) Dependence on festivals

Apart from similar activities offered in other coast towns, such as fishing and bird-viewing, visitors mainly are attracted by Port Fairy's festivals. It leads to a rather mono-sources of income for the local tourism. The following Table 1 shows the intense festivals in Port Fairy:

(2) Issues towards the relocation of Folk Festival

Apart from the local context of tourism development, there are some issues ignored in the initial recommendation towards the relocation of Folk Festival.

a) The needs to invest the facilities for Folk Festival

As the Folk Festival is increasingly popular, current facilities may not satisfy the growing needs for transports and staging equipment, investments are needed. However, constructions of new Port Fairy and new facilities are lengthy process and require injection of consistent funds which lays a heavy burden on financial support.

b) The challenge to make new festival

\begin{tabular}{|c|c|}
\hline & Visitors \\
\hline Domestic day trip average & $61,729(26 \%)$ \\
\hline Domestic overnight trip average & $157,822(67 \%)$ \\
\hline International overnight trip average & $17,581(7 \%)$ \\
\hline
\end{tabular}

Figure 5. National \& international visitor survey [15].

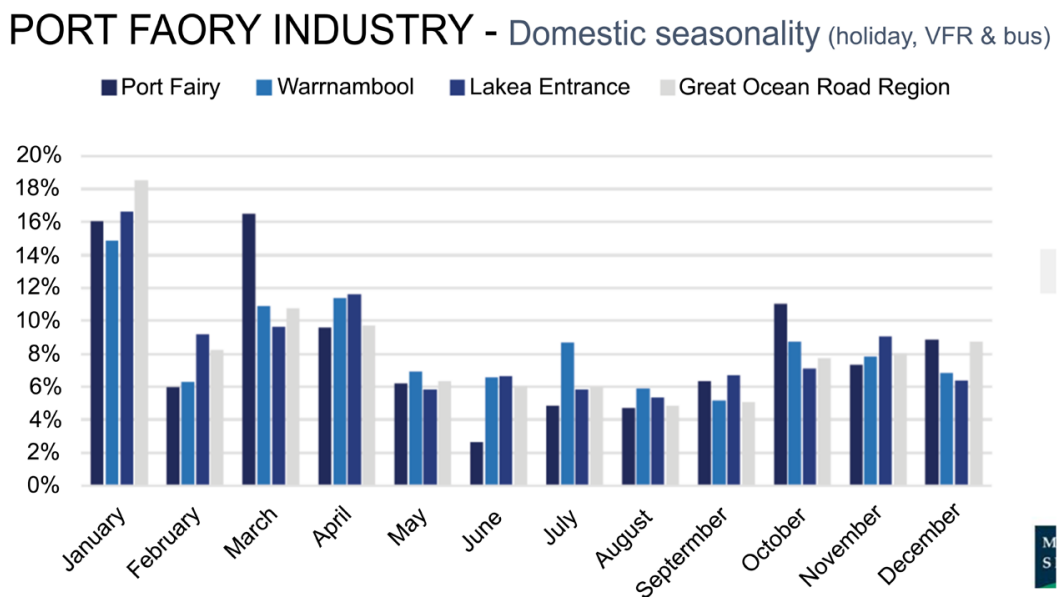

Figure 6. Port fairy industry [15]. 
Table 1. Festivals in port fairy in 2017 [12].

\begin{tabular}{cc}
\hline Time schedule & Festivals \\
\hline $24 / 12 / 2016-27 / 01 / 2017$ & Moyneyana Festival \\
$03 / 03 / 2017-06 / 03 / 2017$ & Port Fairy Folk Festival \\
$04 / 017$ & Koroit Irish Festival \\
$06 / 2017-07 / 2017$ & Winter weekends Port Fairy \\
$09 / 2017$ & Port Fairy Ex Libris Festival of words \\
$10 / 2017$ & Port Fairy Spring Music Festival
\end{tabular}

A problem that may rise from the relocation is how to keep or innovate the characteristics of Folk Festival in new town to incorporate some new elements for the event to attract extra visitors.

\subsection{Conclusion}

In regards to the recommendation, both gradual retreat and relocation of the Folk Festival are feasible, however some issues still need further consideration. Hence, the following actions plan will propose corresponding actions to help in resolving these issues.

\section{Actions Plan}

This actions plan intends to assume the new address for relocating Port Fairy. Then, three stages of actions will be discussed.

\subsection{Relocate Port Fairy}

A new site is chosen as shown in Figure 7. The reasons to support the choice are:

Geographically, it is outside the flooding zone in year 2100 (the flood area has been shown in Figure 8), which minimizes the flood risks. Moreover, the new site is located near the Princess Highway, which provides convenient transport.

In terms of planning law and land use, the site is currently in the Farming Zone according to Moyne Planning Scheme. No permit is required for building dwellings while permissions are required for constructing car parks, group accommodations, leisure and recreations, residential hotels and restaurants [14]. Local council might negotiate with the state government for seeking ownership of the land and land development rights for new Port Fairy.

\subsection{Detailed Actions in Different Stages}

The first stage (the short term 5 - 10 years) is towards assuming change and uncertainty while the second (the medium term $10-20$ years) and third stage (the long term 20 - 50 years) focus on nurturing conditions for recovery and renewal after disturbance.

1) Stage 1 (5 - 10 years) -Strategic foresight and preparation for retreat

Objective 1: Develop comprehensive master plan towards retreat. 


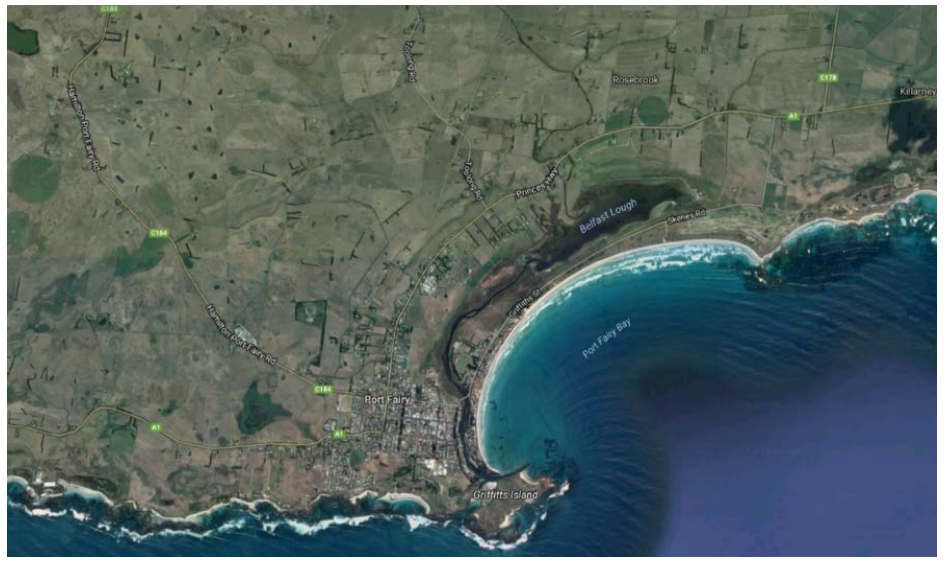

Figure 7. New location of port fairy.

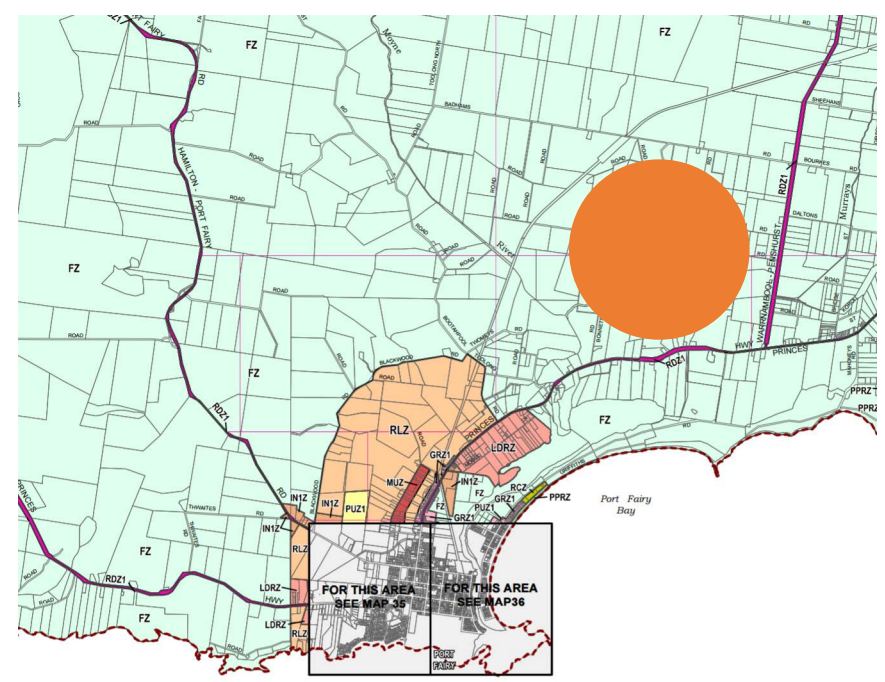

Figure 8. The relationship between new location and current port fairy [15].

a) Action 1: Develop information and technical reports through investigating and researching the current data of residents, number and type of properties, heritage places, commercial or social infrastructures and so on.

Justification: These reports record the current data of town, which is useful for the construction of new town and memorizing the significant history of current Port Fairy.

b) Action 2: Develop plan for building sea walls, emergency alert telephone warning system and the organization of residents' retreat to ensure community safety before retreating.

Justification: Residents and infrastructures cannot relocate immediately, therefore it is necessary to ensure their safety while they are still staying in the original town. Flood-warnings and preventions are suggested by SES (2013) to protect residents from thunderstorm and floods [8].

c) Action 3: Negotiate with State government on Port Fairy's new development of: site selection, land ownership transfer, rights of land use and development, funds support. 
Justification: To develop the Farming Zone, state government's permission is needed [16], hence negotiation with state government towards this site is required. Besides, it also needs the financial support from state government for the new development and removal.

4) Action 4: Develop new Port Fairy's plan that ensures resource conservation through emphasising the use of recycled materials from original site.

Justification: Sustainable management of resources is highlighted in the tourism resilience [3]. Through recycling the materials in the original town, it helps reduce the waste and promote resource efficiency.

5) Action 5: Raise funds from a wide range of governments, NGOs, community groups, Tourism Victoria and local tourism industry. Public-private partnerships can also be supported that help raise funds from private sector and release the financial burdens on the governments.

Objective 2: Ensure all stakeholders involved in the preparation process.

a) Action 1: Hold public consultations before and during the development of master plan to ensure everyone' voice are heard, key issues and outcomes identified in the consultations should be used to amend the master plan.

b) Action 2: Set up retreat association consisting of community members that help strengthen the communication with local council and keep informed towards the retreat plan.

Justification: As Cochrane suggests, stakeholder cohesion and associative working not only reflect the social justice but also highlight the sustainable development which take the next generations' needs into account [2].

Objective 3: Develop tourism retreat plan through incorporation with key stakeholders.

a) Action 1: Formulate a marketing strategy through inter-corporation with key stakeholders that clarifies the destination positioning, maintain and extend the cooperation with domestic and international travel agencies, Great Ocean Road Regional Tourism, Tourism Victoria and so on.

Justification: Cochrane stresses that successful engagement with the market is vital for the development of tourism industry. Through coordination with stakeholders in different scales, internal and external communication is strengthened [5].

b) Action 2: Develop a comprehensive and considerate plan for the relocation of festivals, including the construction and improvement of necessary facilities, the advertisements, and signs to guide the new address, particularly reinforcing the characteristics of Folk Festival.

Justification: Particular plan should be made in order to protect the traditional and representative festivals from loss of characters and attractions.

c) Action 3: Design new attractive tourism products around the year such as Community gardens and food tours can be taken into consideration. Besides, a museum made of recycled materials of old town will be designed as well to store the memory and history of the original Port Fairy, which can also be a unique landmark, as the following Figure 9. 


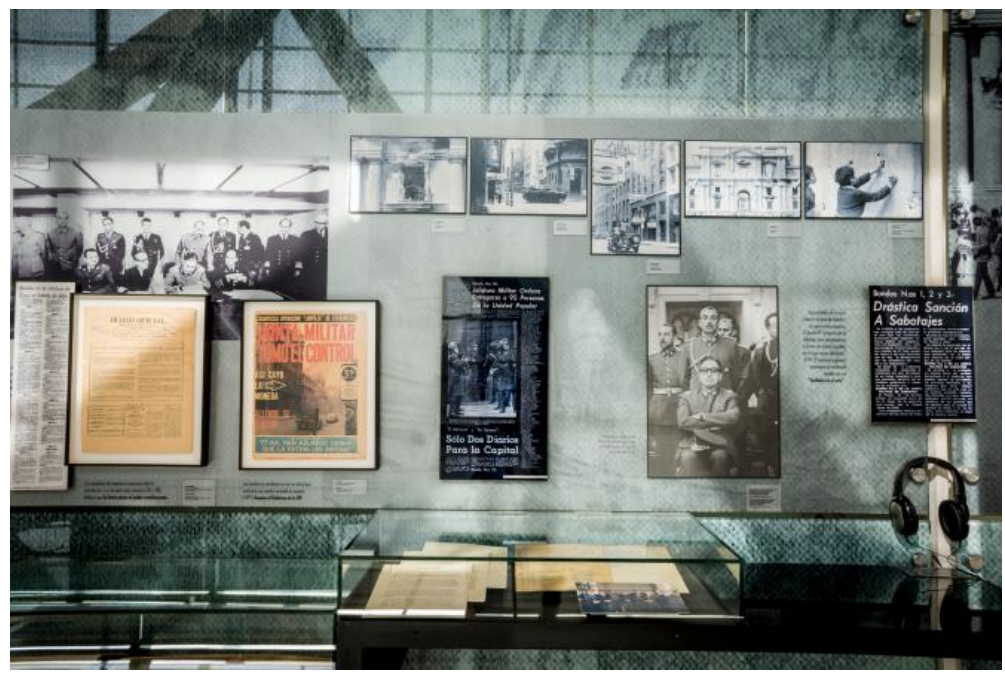

Figure 9. Memory museum [17].

Justification: The current tourism industry has high dependency on festivals and imbalance between different seasons. Hence, it is of significance to improve seasonal dispersal and attractions.

2) Stage 2 (10 - 20 years)-Gradual retreat

Stage 2 is the process of gradual retreat, focusing on the implementations of plans (master plan, tourism retreat plan) prepared in Stage 1.

Objective 1: Ensure accurate implementation of master plan and tourism plan with the strong and effective leadership.

a) Action 1: Construct the properties and infrastructures according to priorities, including the first new development of infrastructures for the elders and the children, the basic social infrastructures such as roads, community centres and stages for festivals.

b) Action 2: Develop the cooperation between the planning team and retreat association to lead the implementation process. The planning team supervises the construction while retreat association helps educate residents about relocation matters and solve problems residents may suffer.

c) Action 3: Set up finance office to supervise financial expenses on the constructions in order to control the budget. Unnecessary costs and expenses can be cut down to ensure the most efficient usage of funds.

d) Action 4: Amend the design and plan in case of sudden accidents through the construction process to ensure least influence on the construction and promote efficient process.

Justification: The implementation should be accurately taken according to the master plan and tourism plan in the preparation stage. And amendments are allowed once there are some accidents in the construction process.

Objective 2: Ensure sufficient coordination between residents' retreat and constructions of new properties and infrastructures.

a) Action 1: On the basis of constructing the infrastructures and properties according to priorities, orderly organize the sequence of residents' retreat. The 
families that have elders, the children and disabled are placed first to move.

b) Action 2: Periodical inspections are made by the retreat association and immediate feedbacks are given to ensure the constructions can satisfy the needs of residents.

Justification: As the process of retreat is lengthy, the original site has the possibility of experiencing floods and storms. Hence, the disadvantaged groups should be first to move. Besides, effective feedbacks towards the constructions can promote the outcomes of the retreat.

Objective 3: Ensure efficient administration and maximum utilization of resource of the original site.

a) Action 1: Efficiently administrate the original site and community safety throughout the process of retreat including constructions of sea walls, educating the residents that haven't moved about alert telephone warning system.

b) Action 2: Make full advantages of the materials in the original site and supervise the design of museum which is made of recycled materials.

Justification: Efficient administration can ensure the safety of residents before retreat and maximum utilization of resource is a way to reduce the waste of the original site.

Objective 4: Ensure rational relocation of tourism attractions particularly festivals.

a) Action 1: Review and strengthen visitors way-finding road signing along the Princess Highway and the original site.

b) Action 2: Supervise the constructions of the infrastructures for festivals and ensure the tourist capacity of the facilities and infrastructures.

Justification: The relocation of festivals may be strange to both frequent tourists and new visitors therefore the road signs are important. The sufficient capacity of facilities and infrastructures can support the expansion of festivals.

3) Stage 3 (20 - 50 years) - settle down in the new site

Objective 1: Ensure satisfying settlements of the whole community.

a) Action 1: Investigate the residents' satisfactions of settlement in the new site including the satisfactions on the community infrastructures and facilities, housing and landscape, the relocation of festivals especially Folk Festival.

b) Action 2: Adaptations and improvements are made according to the feedbacks from the investigations to provide better conditions for residents.

Justification: The recommendations and feedbacks from residents towards settlements in the new site can help promote a continuous development of community services.

Objective 2: Develop and maintain tourism industry in the New Port Fairy.

a) Action 1: Continuous efforts to develop and maintain tourism products and experiences to meet the demand of tourists and market.

b) Action 2: Design an event festival called "Last tour to Port Fairy in our memory" that calls for frequent tourists who had been to Port Fairy before to 
take the last visit to the original Port Fairy and have a perception of New Port Fairy.

Justification: Development of tourism industry should be kept on the basis of market and tourists preferences. The event "Last tour to Port Fairy in our memory" can be regarded as typical event tourism to attract tourists.

\section{Conclusion}

Based on strategies for resilience and tourism resilience, the action plan is implemented by 3 detailed stages. Stage 1 can be thought as the most significant stage for preparing and planning, which lays a good foundation for stage 2 and 3. The stages with certain objectives could be considered as a guidance for retreating similar cities especially for the cities relying on tourism under the similar context. With the increasing challenge brought by climate change and sea level rising, the article proposes appropriate plan and actions to suggest the future development of current coastal tourism destinations. That's to say, plan and actions can be well applied on the tourism destinations affected by sea level rising.

\section{References}

[1] Liao, K. (2012) A Theory on Urban Resilience to Floods-A Basis for Alternative Planning Practices. Ecology and Society, 17, 48.

https://doi.org/10.5751/ES-05231-170448

[2] Davoudi, S. and Porter, L. (Eds.) (2012) Resilience: A Bridging Concept or a Dead End? Special Issue of Planning Theory \& Practice, 13, 299-333.

[3] Beilin, R. and Wilkinson, C. (2015) Introduction: Governing for Urban Resilience. Urban Studies, 52, 1205-1217.

[4] Wilkinson, C. (2012) Social-Ecological Resilience: Insights and Issues for Planning Theory. Planning Theory, 11, 148-169. https://doi.org/10.1177/1473095211426274

[5] Cohrane, J. (2010) The Sphere of Tourism Resilience. Tourism Recreation Research, 35, 173. https://doi.org/10.1080/02508281.2010.11081632

[6] Jeffrey et al. (2016) Tourism in Port Fairy.

[7] Bishop, W., Russell, K. and Little, M. (2010) Impacts of Sea Level Rise on Flooding in an Estuarine Environment. Climate Change 2010: Practical Responses to Climate Change, 60-72, Informit Engineering Collection, EBSCO Host, Viewed 4 December 2016.

[8] SES (2013) Local Flood Guide Port Fairy. Victoria, Australia Availability: Shire of Moyne, 20.

[9] Water Technology 2010, Port Fairy Regional Flood Study Addendum-Sea Level Rise Modelling, Viewed 3rd December.

[10] Tourism Research Australia-National \& International Visitor Survey, Data for Year Ending March, Accessed August 2016.

[11] State Government of Victoria 2016, Moyne Planning Scheme, Viewed $2^{\text {nd }}$ December. http://planning-schemes.delwp.vic.gov.au/schemes/moyne

[12] Great Ocean Road Regional Tourism Limited 2014, Port Fairy Destination Action Plan 2015-2017, Viewed 2rd December 2016. 
http://greatoceanroadtourism.org.au/wp-content/uploads/2015/01/Port-Fairy-WEB -version-final-10-Feb.pdf

[13] UQ E-Heritage (2014) Moyne River Training Walls. Viewed 24 November. http://vhd.heritage.vic.gov.au/vhd/heritagevic\#detail_places

[14] Victoria Coastal Council (2014) Victorian Coastal Strategy 2014. State Government of Victoria, Viewed 24 November.

[15] Wyss, R., Luthe, T. and Abegg, B. (2015) Building Resilience to Climate Change-The Role of Cooperation in Alpine Tourism Networks. Local Environment, 20, 908-922. https://doi.org/10.1080/13549839.2013.879289

[16] Orchiston, C., Prayag, G. and Brown, C. (2016) Organizational Resilience in the Tourism Sector. Annals of Tourism Research, 56, 145-148. https://doi.org/10.1016/j.annals.2015.11.002

[17] Bhati, A., Upadhayaya, A. and Sharma, A. (2016) National Disaster Management in the ASEAN-5: An Analysis of Tourism Resilience. Tourism Review, 71, 148-164. https://doi.org/10.1108/TR-12-2015-0062 